\title{
B-FRESH: DESIGN AND DEVELOP THE MARKETING PROCESS FRUIT COMMODITIES WITH HEDGING SYSTEMS TO PROTECT PRICES WHEN THE HARVEST
}

\author{
Anak Agung Gde Satia Utama \\ Fakultas Ekonomi dan Bisnis, Universitas Airlangga \\ gde.agung@feb.unair.ac.id \\ Elfrida Realisani \\ Fakultas Ekonomi dan Bisnis, Universitas Airlangga \\ elfrida.realismi-2015@feb.unair.ac.id
}

\begin{abstract}
Farmers always get a selling price that is much lower than the cost that they incur so they are forced to lose it. So far, farmers always believe in the prices offered by middlemen or collectors, even though the prices offered do not necessarily cover the expenses of farmers. To solve this problem, a B-fresh system was created that can protect farmers' hard work by hedging or hedging the harvest price. Commodities that are protected by price are fruit commodities because these commodities are still vulnerable to market price game. The development of this system requires cooperation with BUM Desa (Village-Owned Enterprises) as an operator so that this system can run well and properly. This system will process hedging automatically by determining the hedging price to be adjusted to the farmer's land area multiplied by the estimated fair value. BUM Desa (Village-Owned Enterprises also acts as an intermediary for third parties using an e-commerce system to market products and inform product details to consumers that are already present inside this B-fresh system.
\end{abstract}

Keywords: b-fresh, comodity, e-commerce, hedging.

\begin{abstract}
Abstrak
Petani selalu mendapatkan harga jual yang jauh lebih rendah dari biaya yang mereka keluarkan. Sejauh ini, petani selalu percaya pada harga yang ditawarkan oleh tengkulak atau pengumpul, meskipun harga yang ditawarkan belum tentu menutupi biaya petani. Untuk mengatasi masalah ini, sistem B-fresh dibuat yang dapat melindungi kerja keras petani dengan lindung nilai atau lindung nilai harga panen. Komoditas yang dilindungi oleh harga adalah komoditas buah karena komoditas ini masih rentan terhadap permainan harga pasar. Pengembangan sistem ini membutuhkan kerja sama dengan BUM Desa sebagai operator agar sistem ini dapat berjalan dengan baik dan benar. Sistem ini akan memproses lindung nilai secara otomatis dengan menentukan harga lindung nilai yang akan disesuaikan dengan luas lahan petani dikalikan dengan estimasi nilai wajar. BUM Desa (Badan Usaha Milik Desa juga bertindak sebagai perantara bagi pihak ketiga menggunakan sistem e-commerce untuk memasarkan produk dan menginformasikan detail produk kepada konsumen yang sudah hadir dalam sistem B-fresh ini.
\end{abstract}

Kata Kunci: b-fresh, komoditi, e-commerce, lindung nilai.

JEL: M31 


\section{Research Background}

Based on the information reported by the Suara Jatim Post (2015), dragon fruit farmers in Banyuwangi were not happy because the price of dragon fruit dropped dramatically compared to the previous harvest season. This causes farmers do not get benefit from the dragon fruit they harvest. Factors that caused the price of dragon fruit dropped, partly because of the rainy season and harvest season of dragon fruit along with other fruit harvest seasons such as oranges and mangoes. Other information obtained from kbr.id-nusantara, published on April 2, 2015 reported that the price of mangosteen fruit plunged freely to the price of Rp 4,500, per kilogram. This happened during the mangosteen harvest season in Banyuwangi Regency.

The problem faced by farmers is because when the harvest season arrives, the fruit supply is abundant while market demand falls. So farmers are forced to sell their fruits at low prices so that the stock of fruit is reduced, and the effect is that farmers experience losses. The right solution to protect the price of fruit commodities at harvest time by applying a hedging system to farmers. This hedging system helps farmers minimize losses when market prices are unstable because with the hedging system farmers can protect the selling price of fruit commodities before the harvest is done. However, it should be noted that the level of knowledge of farmers regarding the hedging system is low, so many of them do not carry out hedging systems. Therefore, assistance is needed to help fruit farmers in Banyuwangi to have a business strategy for selling fruit commodities, especially when the harvest season arrives. The party that is considered competent enough in assisting the hedging process for farmers is Village-Owned Enterprise (BUM Desa).

Based on the problem identification, the author proposes a website design named BFresh which functions to build a hedging system on fruit commodities in Banyuwangi. In addition to building a hedging system, the website is also useful as a marketing medium for fruit commodities that has been hedged by BUM Desa online and based on e-commerce. Based on the background of the problems mentioned, the research questions can be concluded, namely, how the system design of the marketing process on the B-Fresh website in implementing a hedging system is to protect the value of fruit commodities during the harvest season.

The purpose and benefit of this research is to produce a marketing process design for fruit commodities in Banyuwangi with a hedging system through e-commerce-based B-Fresh website to overcome the problem of dramatic price drops experienced by farmers of fruit commodities during harvest time.

Hedging is actually an old practice and is commonly used in the financial industry which aims to mitigate the risk of financial assets movement such as exchange rates (Difi 2013). Hedging is used in three instruments, namely forward, future and option. All three instruments have differences in in term treatment from creation until the completion of the contract. The hedging system used in the development of the B-fresh system is forward contract hedging, where money will be paid when the terms of the contract have been fulfilled (Stephen 2003). Forward contracts are more likely to cash transactions, meaning that the contract transaction will be completed if there has been an exchange of money and goods.

The agricultural contract system that is almost the same as the system used by B Fresh, is previously used by one of the companies in Thailand, namely Swift Co. Ltd. The company uses a contract system to protect the fixed price value from the acquisition of the best asparagus from the farmer's predetermined fields so that prices can be guaranteed for the whole year. Because of the usefulness of this contract to control the quality and quantity of the product so that the type of contract is written three years and signed by both parties, the contract can be extended after every three years. Although the company will continue to renew the contract every three years, the farmer is free not to continue the contract. 
The flow in the contract system starts from the signing of a contract by farmers and companies, after which the process of growing asparagus from seeds takes around eight months. Harvesting each plant can then begin every two months from the eighth month, taking a gap of one month between each harvest. Thus, asaparagus plots produce four times a year. Furthermore, the asparagus supply must be certified as organic, in this case the Swift company threshs some of the techniques that have been paid by the company to direct farmers to grow asparagus by organic farming. And finally all of the agricultural products will be collected at the company's warehouse and then transferred directly to several supermarkets that have collaborated with companies in the London area. Every farmer who is included in the contract must follow the rules held by the company and if it violates it will be issued in the contract and groups of farmers who work with the company and are prohibited from returning or recontracting with the company.

Supply chain management is a series of approaches that are used to integrate suppliers, manufacturers, warehouses, and stores efficiently, so that merchandise is produced and distributed in the right amount, to the right location, at the right time, to minimize the costs of the entire system and meet requirements customer service level (Levi et al. 2000).

The supply chain network starts from the supplier (supplier or the party that provides the raw materials for production), then continues with the manufacturer (factory that will process the raw material into finished goods), the finished goods are ready to be distributed to customers through distributors, in addition distributors or wholesalers (usually producers will also distribute it to retail outlets), from these distributors the goods will arrive at customers.

\subsection{Village-Owned Enterprise (BUM Desa)}

According to the Regulation of the Minister of Village, Development of Disadvantaged Regions, and Transmigration of the Republic of Indonesia Number 4 Year 2015 concerning Establishment, Supervision and Management, and Dissolution of Village-Owned Business Entities, Village-Owned Enterprises, hereinafter referred to as BUMDesa, are business entities whose entire or part owned by the Village through direct participation originating from village assets that are separated to manage assets, services and other businesses for the greatest welfare of the village community. The establishment of BUM Desa is intended as an effort to accommodate all activities in the economic field and or public services managed by the Village and or inter-Village cooperation. In addition to the regulations issued by the Minister of Village, Development of Disadvantaged Regions, and Indonesian Transmigration, the Establishment of BUM Desa is based on Village Regulations on the Establishment of BUM Desa.

HTML (Hypertext Markup Language) is a page description language that creates hypertext or hypermedia documents. HTML includes a control code between the specified document that creates a link (hyperlink) to another part of the document or to another document anywhere on the World Wide Web. HTML embeds code control in ASCII text from documents that designate titles, titles, graphics, and multimedia components, and hyperlinks in documents (O’Brien and Marakas 2011).

Data mining is the main use of data warehouses and static data contained. In data mining, data in the data warehouse is analyzed to reveal hidden patterns and trends in historical business activities. This analysis can be used to help managers make decisions about strategic changes in business operations to gain competitive advantage in the market. (O'Brien and Marakas 2011).

Agricultural contracts were used in the expansion of rice field areas, intensification of rice production, increased commercialization of rice, and higher prices at the farm level, and ultimately contributed to rice output growth and increased income. The author's findings indicate that contract farming can contribute to improving the rice supply chain and the development of the rice sector in Benin (Maertens and Velde 2017). Well-designed contracts 
can be important for smallholders to benefit from oil palm blasts. The village level approach has clear advantages for evaluating direct and indirect economic impacts, but also has weaknesses in terms of analyzing environmental effects and problems of injustice in the village (Gatto et al. 2017). The built-in e-commerce system can help Mahkota Banana Stores to introduce e-commerce websites and help market bananas sold to all customers, also can manage product data, customer data and ordering data. Based on the results of black box testing, the e-commerce system that was built, was in accordance with what was expected and could function properly (Sugiarti 2014).

Regarding the security of online selling and buying transactions consumer feels good with the confirmation of payment from the Small Market to consumers and if there is an error or overpayment by consumers, Pasar Kecil will immediately contact and confirm the return or use it for the next subscription period (Harimurti et al. 2016).

\section{Research Method}

This type of research is qualitative research with a descriptive approach. This study resulted in a hedging system applied to fruit commodity farmers in Banyuwangi through the BFresh website.

Sources of data in this study are come from primary data and secondary data. Primary data was obtained from interviews with fruit commodity farmers. In addition to primary data interviews, it was also obtained by observing the situation of the price of fruit commodities in the market during the harvest. While secondary data was obtained through data on the number of BUM Desa in Banyuwangi Regency and literature and articles relevant to the research.

According to Miles and Huberman (2014), analysis activities consist of three lines of activities that occur simultaneously, namely data reduction, data presentation, and conclusion or verification.

\subsection{Data Reduction}

Data reduction is defined as the selection process, concentrating attention on simplifying, abstracting, and transforming gross data that arises from written records in the field. Data reduction is a form of analysis that sharpens, classifies, directs, discards unnecessary, and organizes data in such a way that the final conclusions can be drawn and verified.

\subsection{Data Presentation}

Data Presentation is a technique of checking the validity of data that uses something else in comparing the results of interviews with research objects (Moloeng: 2009). Data presentation or triangulation can be done using different techniques, namely interviews, observations and documents. This triangulation is not only used to check the truth of the data, but also to enrich the data. In this study, data is presented in the form of documents in the form of system design diagrams.

\subsection{Conclusion or Verification}

The third analysis activity is to draw conclusions and verifications. This stage is the stage of drawing conclusions from all data that has been obtained as a result of the research. Drawing conclusions or verification is an attempt to find or understand meaning or meaning, order, patterns, explanations, paths of cause and effect or propositions. Before making conclusions, data reduction, data presentation and conclusions or verification can be carried out before the previous activities.

\section{Result and Discussion}

B-Fresh is an e-commerce website designed to build a hedging system for fruit 
commodities in Banyuwangi. The party that conducts hedging is the farmers and the website user, in this case is BUM Desa. The process of marketing fruit commodities to consumers begins when the hedging has been agreed between the farmers and BUM Desa. The price of a hedging agreement will be calculated automatically through the website. Where the price has calculated the maintenance burden incurred by farmers based on the area planted with fruit commodities, so farmers will benefit through a hedging system designed on the B-Fresh website.

Conventional marketing process where farmers sell fruit yields to collectors at bargain prices by offering cheap purchase prices. Due to of this, the farmers will directly experience significant losses because the purchase price is not proportional to the costs incurred for farming and maintenance. The right solution to protect the price of fruit commodities at harvest time is to apply a hedging system to farmers. This hedging system helps farmers minimize losses when market prices are unstable because with the hedging system farmers can protect the selling price of fruit commodities before the harvest is done.

The following is a design of the B-Fresh system that describes how the B-Fresh system works.

\subsection{Data Flow Diagram}

Data flow diagram is a representative graph that describes the flow of information that is applied as data that governs input and output (Sukamto and Shalahuddin 2014). Here is the DFD from the B-Fresh application system:

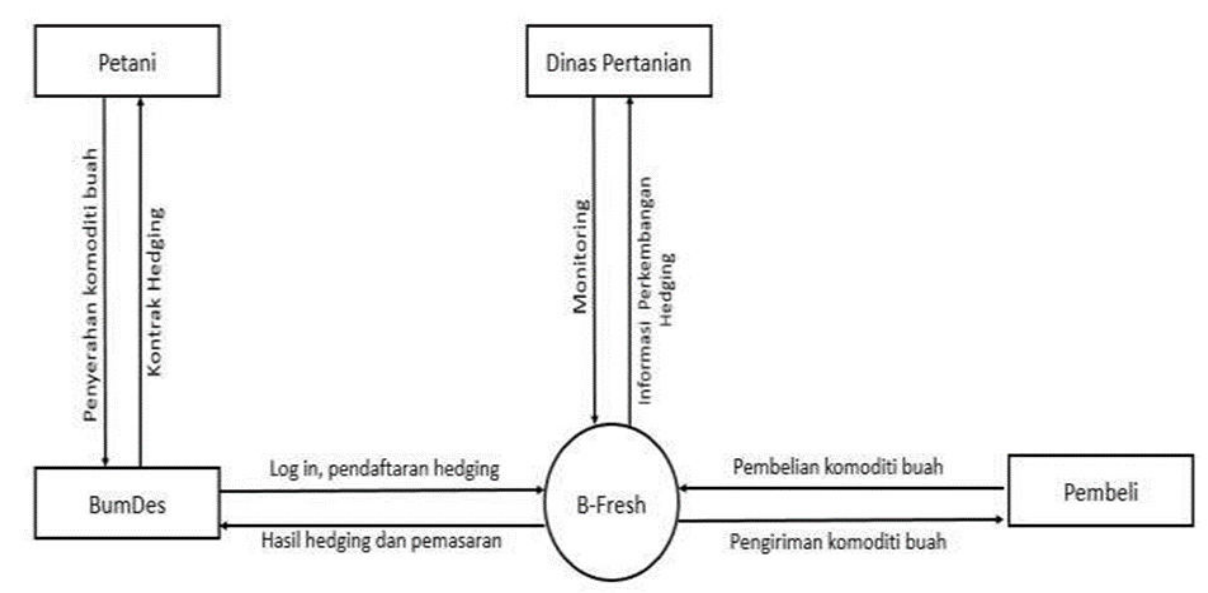

Figure 1. Data Flow Diagram - B-Fresh

\subsection{Flowchart}

Krismiaji (2010) in his book, titled "Accounting Information Systems", explains that water charts are analytical techniques that are used to explain aspects of information systems clearly, precisely and logically. Flowchart uses a series of standard symbols as well as to describe the flow of data in a system. 


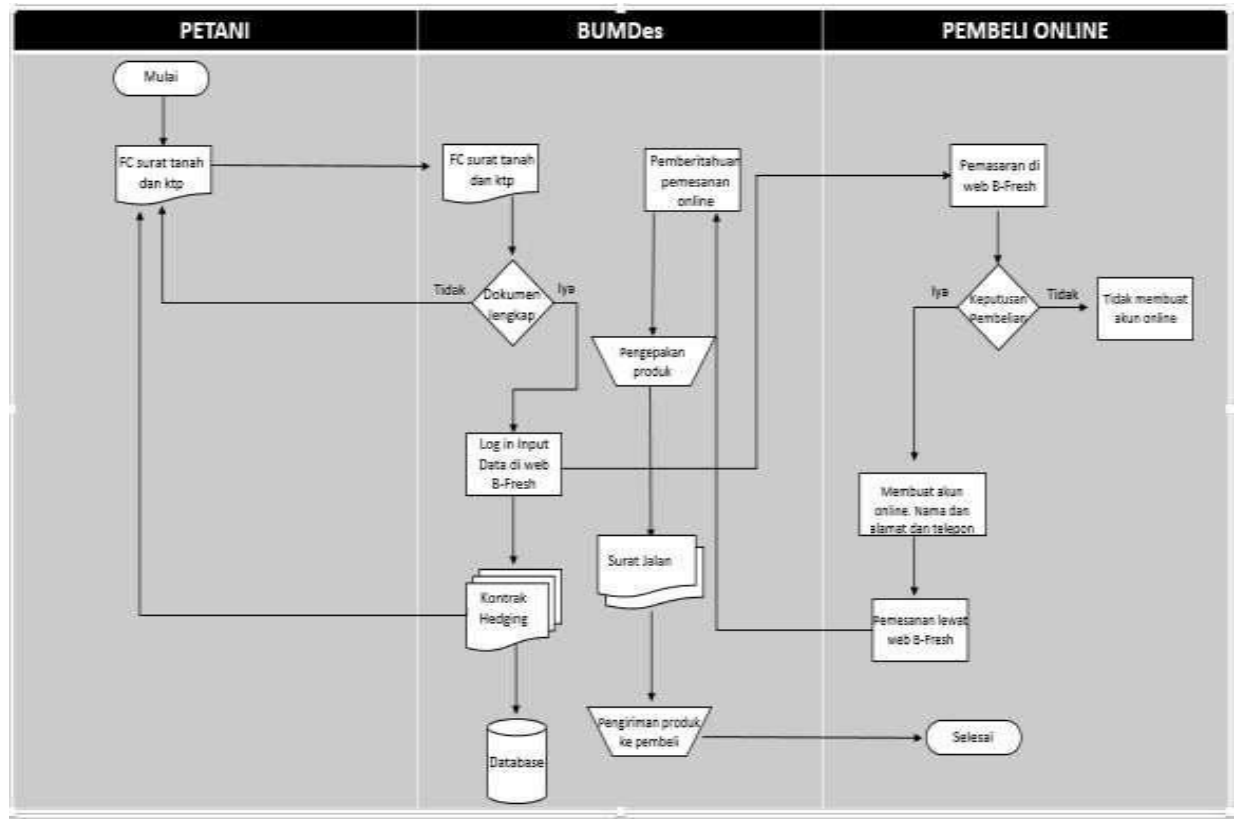

Figure 2. System Flowchart - B-Fresh

\subsection{How B-Fresh Works}

a. Each farmer submit a Copy of KTP (Kartu Tanda Penduduk, Indonesian Identity Card) and a copy of land certificate to BUM Desa.

b. BUM Desa receives the copy of land certificate and verifies whether it is complete and valid. If complete and valid, land data will be inputted on the B-fresh website and if not valid, the copy of certificate will be returned to farmer.

c. The document that meets these qualifications established by BUM Desa is inputted into the B-fresh website. And the output of the data input is a 3-copies hedging contract. 1 copy is for farmers, 1 copy is for BUM Desa and 1 more copy is used as a copy by BUM Desa.

d. After BUM Desa input data on the B-Fresh website, then the BUM Desa operator will renew the commodity which has previously been hedged on the B-Fresh e-commerce website. This is useful for the process of marketing commodities online.

e. When the data has been updated, buyers can make purchases online through the BFresh website.

f. When the buyer decides to make a purchase, the buyer must make an account on the B-Fresh website.

g. After the account creation is complete, the buyer can choose which commodities are ordered and how many are ordered. The total amount of the price will appear automatically so that the buyer can immediately transfer money to the account listed.

h. Notification of ordering fruit will appear automatically on the B-fresh website managed by the BUM Desa operator.

i. BUM Desa issues a shipping document to deliver goods, namely fruit commodities to the address that matches the address registered by the buyer at the time of making an account.

j. The shipping process is processed by BUM Desa.

In addition to data flow diagram and document flowchart needed to design B-fresh website, the author also illustrates the B-Fresh website business process with images. Figure 4 illustrates the beginning of the hedging bidding process to produce output of hedging contracts 
with farmers. While Figure 5 illustrates the process of fruit commodities deposited on BUM Desa until the process of delivery of fruit commodities to buyers who have ordered online through the B-Fresh website. Thus, Figures 4 and 5 further illustrate the supplier chain management process proposed to build a marketing process with a hedging system through the B-Fresh website.

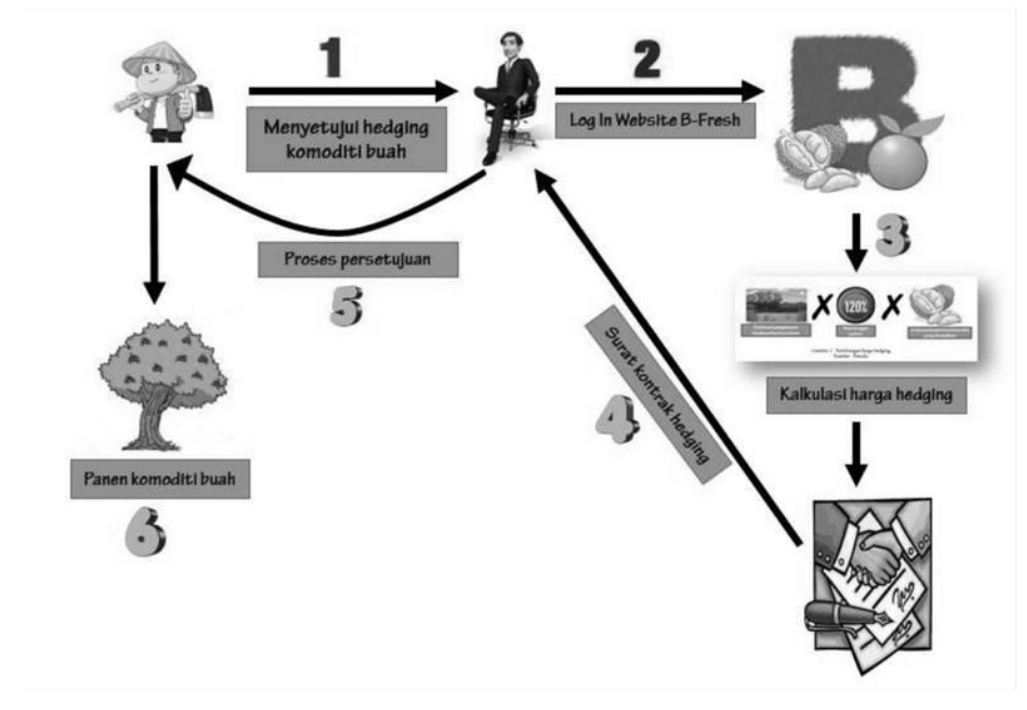

Figure 3. Hedging System Process



Figure 4. Delivery Process of Commodity and marketing

\subsection{Display Design}

The display of the log-in menu on the B-Fresh website managed by BUM Desa is illustrated by Figure 6. The required input data is the user name and password of the operator BUM Desa. Username and password obtained

BUM Desa from the Agriculture Service as controling and monitoring the hedging and marketing system on the B-Fresh website. 


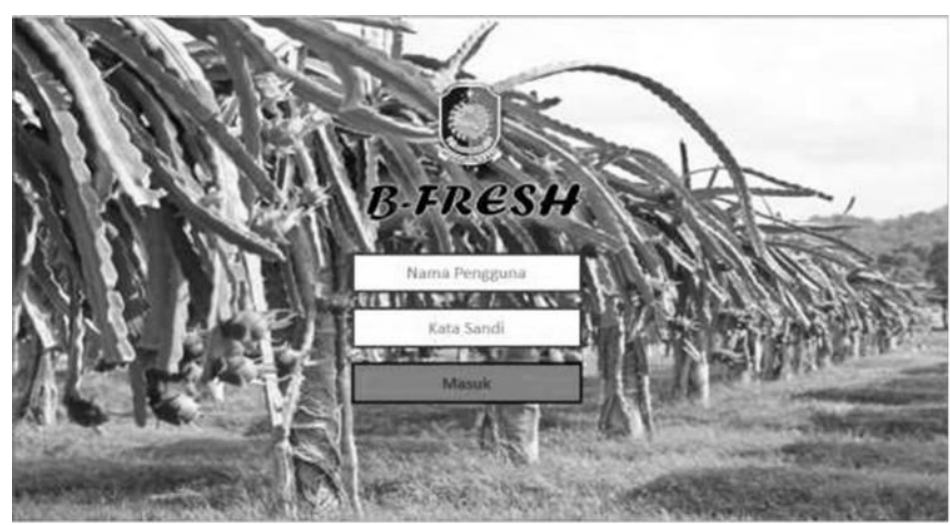

Figure 5. Display of Log-in Menu in B-Fresh Website Managed by BUM Desa

The BUM Desa operator who has obtained a username and password can then access and conduct business processes on the B-Fresh website. The B-Fresh website dashboard has 4 main menus namely Farmer, Product, Hedging and Website.

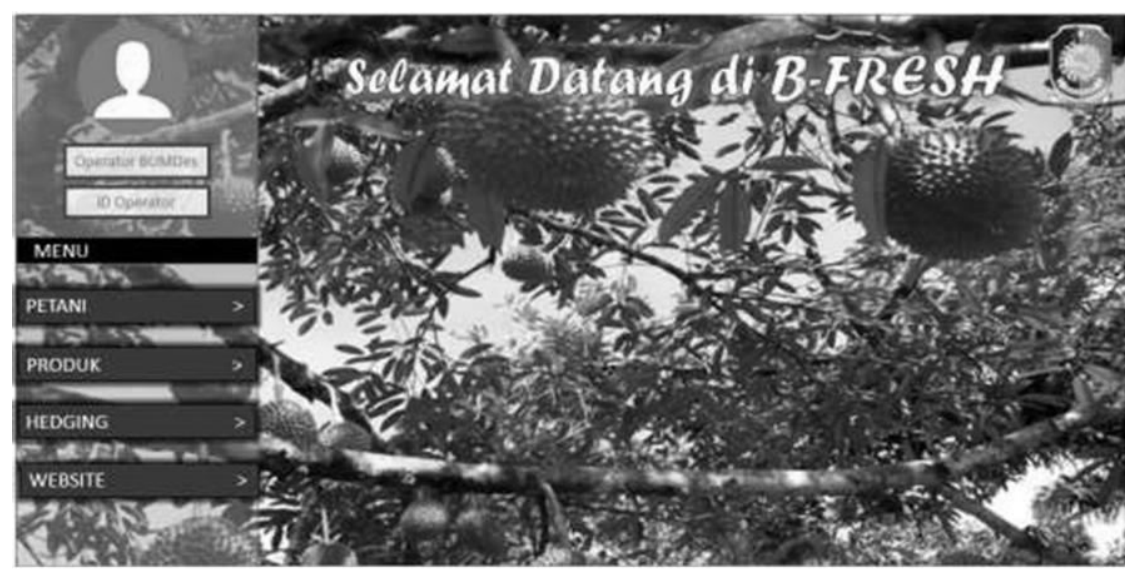

Figure 6. Display of Main Menu of B-Fresh Website

This page is the main page when customers access the B-Fresh website. This page displays a homepage menu that provides news information about fruit commodities. "About Us" menu presents information on the vision and mission of the establishment of the B-Fresh website. The product menu presents information about products sold. My account menu is a menu that functions to register the customer's personal data in order to buy products online. Our contact menu serves to complain about the customer, displayed is the contact number of the Agriculture Service. The Shopping menu is intended for customers who order products, the shopping menu can be used after customers register their personal data on my account. 


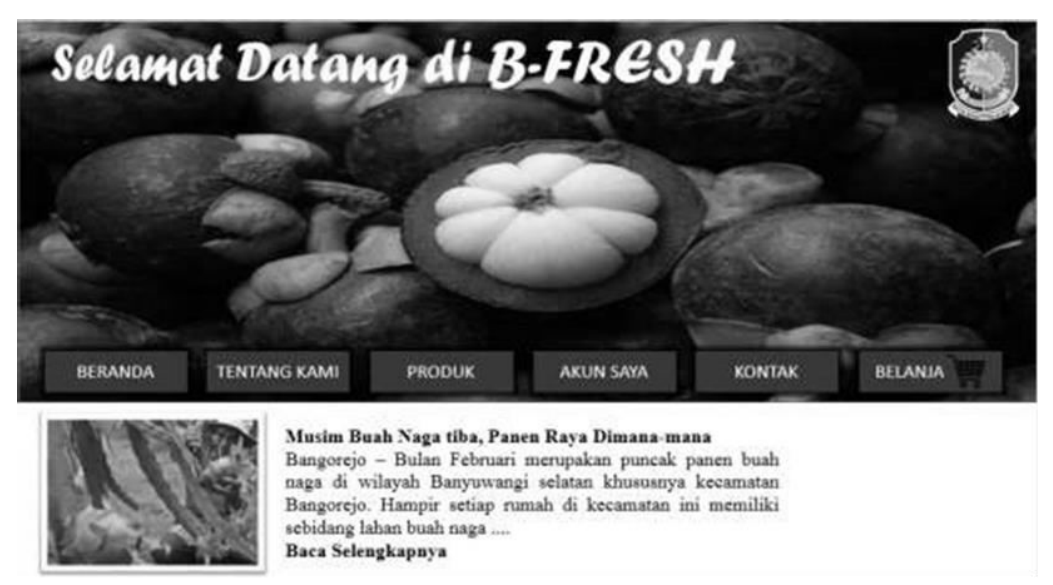

Figure 7. Display of Main Page of B-Fresh Website

The design of hedging system helps farmers to overcome the problems of prices that have drop dramatically during the harvest. Farmers can guarantee prices to BUM Desa and BUM Desa can sell products to consumers through the B-Fresh website by providing detailed information about the fruit commodities being traded. The B-fresh website also facilitates the purchase transaction process without having to come directly to the farmers.

In terms of cost and benefit analysis, this system requires considerable costs such as programmer commission fees, software design, software maintenance, socialization costs to farmers, and BUM Des labor costs to operate the B-Fresh website. However, besides the large costs, this hedging system provides great benefits, especially for farmers. The benefits that farmers will get is an increase by approximately $20 \%$ when using this system rather than not using a hedging system. Even farmers can lose when not using a hedging system, because the selling price is very cheap.

The B-Fresh website adopts HTML technology and chain management supply that uses internet technology in its operation. This system involves several parties, namely the Post, Telecommunication and Tourism Office that serves as monitoring in implementing the hedging and sales system on the B-Fresh website. BUM Desa is the operator in carrying out a hedging system and as an intermediary for hedging information to farmers.

In addition to having the benefits of designing this system also has risks posed in its application. These include the following:

a. Cost is expensive since it requires a lot of of human resources.

b. A long period of time time (that is required to develop the system) is needed since it requires surveying farmers directly.

c. Rollover of BUM Desa Supervisor.

d. BUM Desa's employees have difficulty operating the B-Fresh application.

e. B-Fresh Website socialization can be done in stages and continuous since system will need upgrading from time to time.

f. System requires re-new yearly.

\section{Conclusion}

Based on the discussion described above, conclusions can be drawn as follows: first, marketing of fruit commodities using a hedging system can help overcoming farmers' problems when commodity prices dropped significantly during the harvest. Because the potential losses suffered by farmers will be smaller. Second, the implementation of e-commerce in marketing fruit commodities can help reducing the costs incurred and be able to convey detailed information about products and prices given to consumers online and facilitate the transaction 
process without having to come directly to farmers. Third, the use of the system can help the Banyuwangi District Government in managing fruit commodities, since fruit commodities can be guaranteed by this system and data on fruit commodities are well recorded.

The limitation faced during this study is that system modeling has not been implemented and is still a concept offered by the Banyuwangi district government. Cost and benefit analysis needs to be scrutinized so that more profits are obtained through the hedging system by B-Fresh. It is expected that in the future, the proposed concept can be a guide if this system is implemented in Banyuwangi Regency.

\section{Acknowledgement}

Thank you to the Research Team of this paper. Thank you also to the Assistant as editorial team, Pending Puji and Dian Pratama. And, thank you to the Banyuwangi Regency Government and Airlangga University (PSDKU in Banyuwangi). Thank you to all parties that we cannot mention one by one, for the support, source of data and information provided, so that this article can be completed and ready to be published.

\section{References}

Bank Indonesia. 2013. Gerai Info Bank Indonesia: Lindung Nilai Jaminan dan Pendalaman Pasar. Edisi 43. Jakarta: Humas Bank Indonesia.

Gatto M, Wollnib M, Asnawi R, Qaim M. 2017. Oil Palm Boom, Contract Farming, and Rural Economic Development: Village-Level Evidence from Indonesia. World Development. 95: 127-140.

Harimurti AC, Sadeli AH, Utami HN, Mukti GW. 2016. Strategi Peningkatan Kinerja Atribut Produk Sayuran Melalui Pemasaran Online Dalam Upaya Meraih Kepuasan Konsumen (Studi Kasus Di Pasar Kecil Bandung). Jurnal Agrosains dan Teknologi. 1(2): 47-63

Suara Jatim Post [internet]. 2017. Jember: Suara Jatim Post . [Cited in 2019 March 24]. Available from http://m.suarajatimpost.com/read/10937/20171206/172653/ha rga-buahnaga-di-pasaran-tinggi-di-petani-banyuwangi-anjlok/.

Krismiaji. 2010. Sistem Informasi Akuntansi. Yogyakarta: UPP AMP YKPN.

Levi DS, Kaminsky P, Levi ES. 2000. Designing and Managing The Supply Chain. Singapore: Mac Grawhill.

Maertens M, Velde KV. 2017. Contract-farming in Staple Food Chains: The Case of Rice in Benin. World Development. 95: 73-87.

O’Brien JA, Marakas GM. 2011. Management Information Systems. Tenth Edition. New York: McGraw-Hill/Irwin.

Stephen RA, Randoph W, Jaffe. 2003. Corporate Finance. Sixth Edition. Boston: Mc GrawHill.

Sugiarti Y. 2014. Perancangan Sistem Informasi Agribisnis E-commerce Buah Pisang. Jurnal Agribisnis. 8(1): $71-82$.

Sukamto RA, Shalahudin M. 2014. Rekayasa Perangkat Lunak Terstruktur Dan Berorientasi Objek. Bandung: Informatika Bandung. 